УДК 612.44.014:616.441-091.8

https://doi.org/10.26641/2307-0404.2021.2.234498

\title{
O.B. Федосеєва
}

\section{ІМУНОГІСТОХІМІЧНІ ПОКАЗНИКИ МОРФОФУНКЦІОНАЛЬНОГО СТАНУ ЩИТОПОДІБНОЇ ЗАЛОЗИ В НОРМІ ТА ПІСЛЯ ПРЕНАТАЛЬНОГО АНТИГЕННОГО НАВАНТАЖЕННЯ}

Запорізький державний медичний університет кафедра гістології, цитологї та ембріологї (зав. - д. мед. н., проф. В.К. Сиричов) пр. Маяковського, 26, Запоріжжя, 69035, Украӥна Zaporizhzhia State Medical University Department of Histology, Cytology and Embryology Maiakovskoho av., 26, Zaporizhzhia, 69035, Ukraine e-mail: fedoseeva.ov@zsmu.zp.ua

Цитування: Медичні перспективи. 2021. Т. 26, № 2. С. 40-45

Cited: Medicni perspektivi. 2021;26(2):40-45

Ключові слова: тироглобулін, щчитоподібна залоза, щури, антиген Ключевые слова: тироглобулин, щитовидная железа, крысы, антиген Key words: thyroglobulin, thyroid gland, rats, antigen

Реферат. Иммуногистохимические показатели морфофункционального состояния щитовидной железы в норме и после пренатальной антигенной нагрузки. Федосеева О.В. $B$ ходе индивидуального развития $u$ влияния инфекционных агентов на организм структурные компоненты щчитовидной железы могут существенно меняться. В современных исследованиях большое значение придается изучению механизмов поддержания морфологического гомеостаза щиттовидной железы и представлений о ее структурно-функцุиональной перестройке в условиях реакции иммунной системы организма на различные инфекиии. Экспериментально установлень морфофункичинальные особенности щуитовидной железы новорожденных животных после пренатального действия тиреоид-неспецифического антигена (стафилококкового анатоксина). У антиген-премированных крыс изменяются сроки фолликулогенеза, а также размеры, распределение и иммуногистохимическая экспрессия антител к тироглобулину, функииональное состояние тироциитов и фолликулов по сравнению с нормой. Обнаруженные иммуногистохимические изменения свидетельствуют о признаках морфофункииональной незрелости органа с элементами гипоактивности.

\begin{abstract}
Immune-histochemical indicators of the morpho-functional state of the thyroid gland in norm and after prenatal antigenic exposure. Fedosieieva O.V. During the individual development and exposure to infectious agents of the organism, the structural components of the thyroid gland can change significantly. In modern research, great importance is attached to the study of mechanisms for maintaining morphological homeostasis of the thyroid gland and ideas about its structural and functional restructuring in response to the body's immune system to various infections. The morpho-functional features of the thyroid gland of newborn animals after prenatal action of thyroidnonspecific antigen (staphylococcal toxoid) have been experimentally established. In antigen-premiumed rats, the timing of folliculogenesis changes, as well as the size, distribution and immunohistochemical expression of antibodies to thyroglobulin, the functional state of thyrocytes and follicles compared to normal. The detected immunohistochemical changes indicate signs of morpho-functional immaturity of the organ with hypoactivity elements.
\end{abstract}

Щитоподібна залоза характеризується високою структурною і функціональною лабільністю у відповідь на вплив різноманітних екзогенних чинників. У ході індивідуального розвитку та впливу інфекційних агентів на організм структурні компоненти щитоподібної залози можуть суттєво змінюватись [4, 12]. У сучасних дослідженнях велике значення надається вивченню механізмів підтримання морфологічного гомеостазу щитоподібної залози i уявлень про іiі структурно-функціональну перебудову за умов реакції імунної системи організму на різноманітні інфекції. Особливу увагу в цьому питанні привертає до себе вплив різноманітних чинників на організм вагітної, тобто пренатальна неспецифічна дія зовнішніх інфекційних антигенів на організм, які б мали віддалені прояви після народження [5]. Антигенне навантаження в критичні терміни онтогенезу може викликати значні «поломки» в імунній системі дитини [10]. 
Наслідком перенесених інфекцій може бути ініціація морфологічних змін органів та забар'єрних структур, тобто ці інфекції можуть не призводити до стійких змін структури, а тільки залишати постійний імунологічний «фон» в органі та організмі в цілому, який при впливі різних чинників може в подальшому ініціювати патологічні стани, включаючи автоімунні захворювання і т.д. $[10,15]$. Особливості взаємодії плоду або новонародженого $з$ екзогенними антигенами можуть бути вирішальними у формуванні їх імунного статусу в майбутньому $[7,8,9,13]$. При впливі пренатального антигенного навантаження відбувається передчасний вихід Т-лімфоцитів 3 тимуса, які в тканинах змінюють не тільки терміни розвитку структурних елементів, але i їх імунологічну толерантність і т.д. $[1,2,3]$. Низкою наукових досліджень отримано дані про те, що бактеріальна інфекція може подавати як антиген-специфічний сигнал, так і антиген-неспецифічну підтримку, необхідну для індукування патогенної автоімунної реакції $[6,11,14]$. Тож дослідження морфогенезу щитоподібної залози за умов пренатальної дії антигенів інфекційного генезу $\epsilon$ актуальним та перспективним науковим напрямком.

Мета дослідження - встановлення морфофункціональних особливостей щитоподібної залози експериментальних тварин у нормі та після пренатальної дії тиреоїд-неспецифічного антигену.

\section{МАТЕРІАЛИ ТА МЕТОДИ ДОСЛІДЖЕНЬ}

Матеріалом для дослідження була щитоподібна залоза щурів лінії Вістар у віці від 1 до 7 діб постнатального розвитку (54 тварини), по 6 тварин у кожній групі. Досліджено три групи тварин на 1, 3, 7 добу життя після народження: I гр. - інтактні тварини (норма); II гр. контрольна, тваринам якої вводили $0,9 \%$ розчин $\mathrm{NaCl}$ на 18 добу датованої вагітності; III - експериментальні тварини, яким вводили стафілококовий анатоксин рідкий очищений адсорбований (10-14 одиниць зв'язування у 1 мл, розведений у 10 разів) на 18 добу датованої вагітності за методом Волошина М.А. (пат. 49377, Україна, 2010 та пат. 63020, Україна, 2011). Уведення плодам антигену та $0,9 \%$ розчину $\mathrm{NaCl}$ здійснювалось оперативно під час лапаротомії, шляхом крізьматкової, крізьоболонкової підшкірної ін'єкції у міжлопаткову ділянку в дозі 0,05 мл кожному плоду.

Щитоподібну залозу фіксували в $10 \%$ розчині нейтрального забуференого формаліну протягом доби. Об'єкти заливали в парафінові блоки загальноприйнятим методом. Гістологічні зрізи товщиною 3-5 мкм зафарбовували гематоксиліном й еозином для оглядової світлової мікроскопії та проведення морфометрії.

Імуногістохімічне дослідження використано для встановлення синтетичної активності, оцінки функціонального стану органа та виконано відповідно до протоколу, рекомендованого до конкретного антитіла, фірми-виробника. Використовували Thyroglobulin Antibody (2H11) фірми Santa Cruz Biotechnology, Inc. із застосуванням методу непрямого зафарбовування імунопероксидазою за допомогою кон'югованих HRP мишачих IgG-зв'язуючих білків, m-IgGк BP-HRP, 3 подальшою інкубацією в субстраті пероксидази та суміші хромогену DAB-3-діамінобензидину тетрахлориду та дофарбовуванням ядер гематоксиліном Майера, дегідратацією, просвітленням та заключенням у бальзам.

Результат розцінювали як позитивний при випаданні солей хромогену у вигляді специфічної реакції (цитоплазматична, мембранна реакція залежно від локалізації антигену). Інтенсивність відкладення бензидинової мітки оцінювали в балах за такою градацією: «0»- відсутня реакція, світло-жовте забарвлення. «1»- слабка реакція, світло-коричневе забарвлення; «2»помірна реакція, коричневе забарвлення; «3»інтенсивна реакція, темно-коричневе забарвлення. Проміжні відтінки позначали 0,$5 ; 1,5$ та 2,5 бали відповідно.

3 метою контролю методу була проведена серія досліджень 3 використанням позитивних і негативних зразків, які служили еталонами.

Фотодокументацію досліджуваних об'єктів виконано з використанням мікроскопа Carl Zeiss «Primo Star» 3 використанням камери AxioCam, комплекс морфометричних досліджень виконувся за допомогою програми Zeiss Zen (2017).

Статистичний аналіз отриманих результатів проводили за допомогою персонального комп'ютера на базі операційної системи Windows XP за допомогою статистичного пакету «Statistica for Windows 6.0» (StatSoftInc., серійний номер №AXXR712D833214FAN5), програма Excel (Microsoft Office, USA). Використовували методи варіаційної статистики. Всі результати досліджень фіксувалися в журналах та протоколах первинної документації, а також з використанням електронних носіїв інформації. Достовірність відмінностей між групами оцінювали за допомогою t-критерію Стьюдента-Фішера для рівня достовірності не менше 95\% $(\mathrm{p}<0,05)$. 


\section{РЕЗУЛЬТАТИ ТА ЇХ ОБГОВОРЕННЯ}

При світловій мікроскопії серійних зрізів щитоподібної залози тварин інтактної та контрольної груп 1-ї доби життя встановлено, що паренхіма органа складається 3 фолікулів безколоїдного типу секреції та міжфолікулярних тироцитів. Порожнина в центрі більшості фолікулів не візуалізується або починається формування первинної порожнини (рис. 1, а). Одночасно в пренатально антиген-премійованих тварин експериментальної групи залозистий компонент щитоподібної залози морфологічно більш структурваний: більшість фолікулів мають порожнину 3 оксифільно забарвленим вмістом без крайової вакуолізації. Деякі фолікули мають неправильну форму та інвагінації з тироцитів у просвіт фолікулів, що свідчить про продовження фолікулогенезу. Розміри фолікулів щитоподібної залози тварин експериментальної групи в 1,3 раза достовірно більші порівняно 3 контрольною та інтактною групами, дані яких між собою достовірно не відрізнялися. Експресія антитіл до тироглобуліну (Tg) у щитоподібній залозі тварин I та II груп помірна та візуалізується в цитоплазмі тироцитів. Цитоплазматична $\mathrm{Tg}^{+}$-експресія нерівномірна i має пінний вигляд (рис. 1, a), за рахунок $\mathrm{Tg}^{-}$вакуолей, у той час, як у більшості фолікулярних тироцитів пренатально антиген-премійованих тванин тироглобулін імуногістохімічно не виявляється. ${\mathrm{У} \mathrm{Tg}^{+}}^{+}$ тироцитах експресія відповідного маркера слабка та рівномірно дифузно розподілена в цитоплазмі (рис. 1, б). Причому в порожнистих фолікулах експериментальної групи імуногістохімічно тироглобуліну не виявлено (рис. 1, б). Кількість $\mathrm{Tg}^{+}$-тироцитів тварин III групи в 2,4 раза менша на одиницю площі порівняно з I та II групами.

На 3-ю добу постнатального життя в щитоподібній залозі тварин I та II груп 3'являються поодинокі порожнисті фолікули 3 колоїдним типом секреції, які переважно підкапсулярні. Серед кулястих фолікулів частина неправильної форми. Фолікулярні тироцити кубічної форми лежать на базальній мембрані, щільно з'єднані між собою. Виявляється помірна, місцями інтенсивна цитоплазматична $\mathrm{Tg}^{+}$ експресія фолікулярних тироцитів. Імуногістохімічно в порожнині фолікулів виявляється тироглобулін 3 інтенсивною пристінковою експресією та помірною центральною. Частково в поодиноких фолікулах середнього діаметра візуалізуються дрібні крайові вакуолі резорбції колоїду. У щитоподібній залозі експериментальних тварин у цей період з'являються фолі- кули порожнистого колоїдного типу по всьому об'єму органа. Фолікули середнього діаметра кулеподібної форми локалізовані під капсулою. Інтенсивність експресії $\mathrm{Tg}^{+}$слабка рівномірна по всій порожнині фолікула, навіть пристінково в ділянці вакуолей резорбції. Цитоплазматична $\mathrm{Tg}^{+}$- реакція слабка, але рівномірна у всіх фолікулярних тироцитах.

Співвідношення фолікулів різних розмірів (малі:середні:великі) у тварин інтактної та контрольної груп на 7-у добу становить $3: 1: 0$, а в антиген-премійованих $-1: 2: 1$ відповідно. У співвідношенні тканинних компонентів виявлено зниження питомої площі тиреоїдного епітелію на одиницю площі. Це пояснюється тим, що висота клітин фолікулярного епітелію стає меншою, превалює кубічна і плоска форма тироцитів, циліндричні клітини зустрічаються рідко, переважно у фолікулах малого розміру безколоїдного типу. Середній діаметр ядер достовірно зменшується порівняно 3 контрольною групою і становить 0,25 $\pm 0,01$ мкм. Достовірно зменшилась кількість ядерець у тироцитах на одиницю площі в експериментальній групі порівняно 3 контролем, що становить $22,7 \pm 1,04$ і $34,4 \pm 1,01$ відповідно, що свідчить про зниження процесів синтезу субодиниць рибосом, отже, і валового синтезу білкових продуктів. Виявлено збільшення відносного відсотка площі порожнини фолікулів за рахунок збільшення кількості великих та середніх фолікулів у антиген-премійованих тварин порівняно $з$ I та II групами. Відсутність резорбційних вакуолей у частині фолікулів відповідно супроводжується уповільненням виведення гормонів у кровообіг і призводить до перерозтягнення таких фолікулів i, як наслідок, сплощення тиреоїдного епітелію. Це повністю підтверджується імуногістохімічно наявністтю слабко вираженої $\mathrm{Tg}^{+}$експресії як у цитоплазмі тироцитів, так і помірної в колоїді фолікулів щитоподібної залози антиген-премійованих щурів (рис. 1, г), на відміну від тварин інтактної і контрольної груп, де була інтенсивно виражена реакція в цих структурах (рис. 1, в). У великих фолікулах щитоподібної залози експериментальних тварин також виявлявся $\mathrm{Tg}^{+}$колоїд $з$ ознаками дегенерації (рис. 1, г).

Таким чином, у період новонародженості в нормі в щурів відбуваються значні морфофункціональні зміни паренхіми щитоподібної залози, які характеризуються інтенсивним фолікулогенезом та інтрацелюлярним розвитком синтетичного апарату тироцитів, який характеризується вираженою продукцією прегормона 
(тиреоглобуліну) та гормонів щитоподібної залози. Експериментально доведено, що в пренатально антиген-премійованих стафілококовим анатоксином тварин змінюються строки утворення структурно-функціональних одиниць щитоподібної залози, їх розміри, розподілення та функціональний стан порівняно 3 нормою. Незважаючи на більш розвинену морфологічну будову щитоподібної залози i випередження строків фолікулогенезу порівняно 3 інтактними тваринами, в експериментальної групи імуногістохімічно виявлені ознаки функціональної незрілості органа, які характеризувалися слабкою цитоплазматичною та колоїдною $\mathrm{Tg}^{+}$експресією.
Це є ознакою зниженої білок-синтезуючої функції тироцитів, а майже відсутність вакуолей резорбції та сплощення тиреоїдного епітелію окремих фолікулів є морфологічними ознаками зниження гормон-продукуючої функції щитоподібної залози. При чому така морфологічна картина візуалізувалася на серійних зрізах в обох частках по всій паренхімі органа i не була мозаїчною, що дає нам змогу стверджувати про ознаки морфофункціональної незрілості органа 3 ознаками гіпоактивності.

Конфлікт інтересів. Автор заявляє про відсутність конфлікту інтересів.
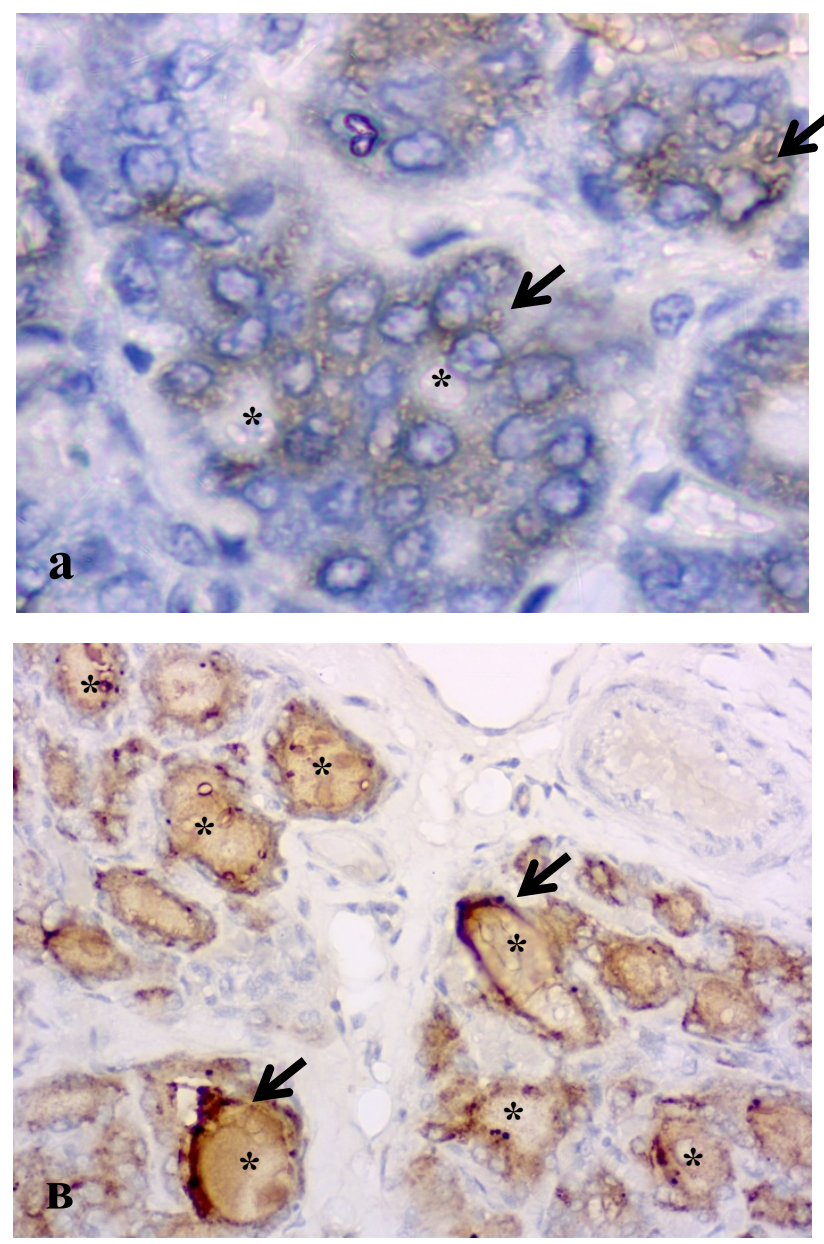
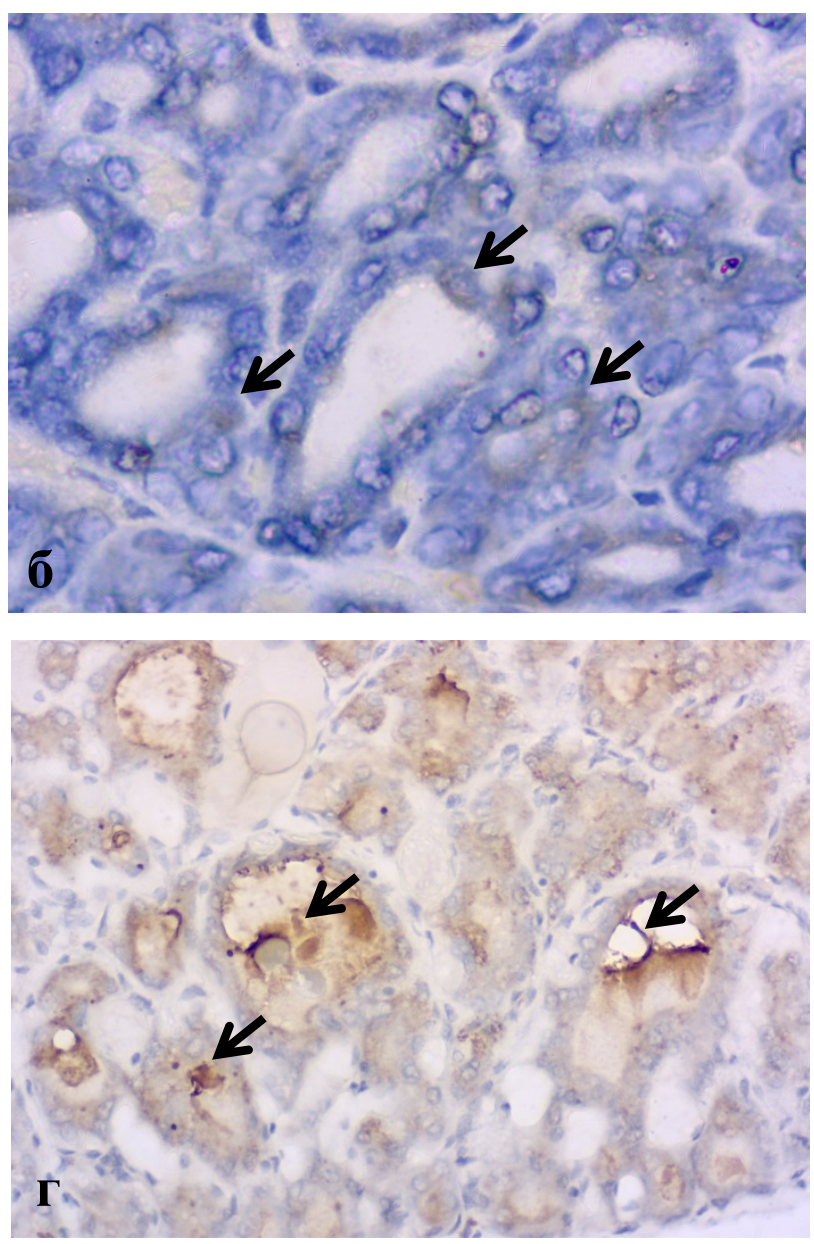

Імуногістохімічна експресія антитіл до тиреоглобуліну в щитоподібній залозі новонароджених щурів лінії Вістар 1 (а, б) та 7 (в, г) доби життя. Збільшення: а, б - х1000; в, г - х400. a - слабка цитоплазматична експресія $\mathrm{Tg}^{+}$у тироцитах фолікулів безколоїдного типу щитоподібної залози щурів контрольної групи (вказано стрілками); зірочками позначено формування первинної порожнини фолікулів.

б - стрілками вказано $\mathrm{Tg}^{+}$тироцити зі слабко вираженою імуногістохімічною експресісю антитіл порожнистих фолікулів щитоподібної залози антиген-премійованих тварин експериментальної групи. в - щитоподібна залоза тварин контрольної групи, стрілками позначено $\mathrm{Tg}^{+}$фолікули 3 інтенсивною цитоплазматичною та колоїдною експресією, зірочками відмічено колоїд з вакуолями резорбції. г - стрілками вказано на колоїд з ознаками дегенерації фолікулів щитоподібної залози тварин після пренатального антигенного навантаження стафілакоковим анатоксином. 


\section{СПИСОК ЛІТЕРАТУРИ}

1. Долгих В., Золотов А. Иммунология. Москва: Изд-во Юрайт, 2020. 248 с.

URL: https://urait.ru/book/immunologiya-455693

2. Здор В. В., Маркелова Е. В., Гельцер Б. И. Новые участники нарушения толерантности к антигенам щитовидной железы: к концепции иммунопатогенеза аутоиммунных заболеваний щитовидной железы (обзор литературы). Медицинская иммунология. 2016. T. 18, № 3. C. 209-220.

DOI: https://doi.org/10.15789/1563-0625-2016-3-209-220

3. Матвєйшина Т. М., Штанько І. Ф. Вплив внутрішньоутробного антигенного навантаження на інтенсивність розподілу рецепторів до сіалоспецифічних лектинів в структурах слизової глотки щурів. Вісник проблем біології $i$ медицини. 2016. Вип. 2, Т. 129, No. 2. С. 214-219.

4. Ткаченко В. І., Максимець Я. А. Фактори ризику виникнення та прогресування автоімунних захворювань щитоподібної залози: систематичний аналіз даних за останнє 10-річчя. Семейная медищина 2017. T. 73, № 5. C. 20-25.

5. Are Perinatal Events Risk Factors for Childhood Thyroid Autoimmunity? / B. Jonsdottir et al. Eur. Thyroid J. 2017. Vol. 6, No. 6. P. 298-306. DOI:https://doi.org/10.1159/000479964

6. Bliddal S., Nielsen C. H., Feldt-Rasmussen U. Recent advances in understanding autoimmune thyroid disease: the tallest tree in the forest of polyautoimmunity. F1000Res. 2017. Vol. 6. P. 1776.

DOI: https://doi.org/10.12688/f1000research.11535.1

7. Harrington W. E., Kakuru A., Jagannathan P. Malaria in pregnancy shapes the development of foetal and infant immunity. Parasite Immunol. 2019. Vol. 41, No. 3. P. e12573. https://doi.org/10.1111/pim.12573
8. Hong M., Bertoletti A. Tolerance and immunity to pathogens in early life: insights from HBV infection. Semin. Immunopathol. 2017. Vol. 39, No. 6. P. 643-652. DOI: https://doi.org/10.1007/s00281-017-0641-1

9. Kan B., Razzaghian H. R., Lavoie P. M. An Immunological Perspective on Neonatal Sepsis. Trends Mol. Med. 2016. Vol. 22, No. 4. P. 290-302. DOI: https://doi.org/10.1016/j.molmed.2016.02.001

10. McLachlan S. M., Rapoport B. Breaking tolerance to Thyroid Antigens: changing concepts in thyroid autoimmunity. Endocr. Rev. 2014. Vol. 35, No. 1. P. 59105. DOI: https://doi.org/10.1210/er.2013-1055

11. Role of genetic and non- genetic factors in the etiology of Graves' disease / M. Marino et al. $J$. Endocrinol. Investig. 2015. Vol.38. P. 283-294. DOI: https://doi.org/10.1007/s40618-014-0214-2

12. The Aging Thyroid: A Reappraisal Within the Geroscience Integrated Perspective / C. Franceschi et al. Endocr. Rev. 2019. Vol. 40, No. 5. P. 1250-1270. DOI: https://doi.org/10.1210/er.2018-00170.

13. The immunologic status of newborns born to SARSCoV-2-infected mothers in Wuhan, China / P. Liu et al. $J$. Allergy Clin. Immunol. 2020. Vol. 146, No. 1. P. 101-109.e1. DOI: https://doi.org/10.1016/j.jaci.2020.04.038

14. The microbiota and autoimmunity: Their role in thyroid autoimmune diseases / H. L. Köhling et al. Clin. Immunol. 2017. Vol. 183. P. 63-74.

DOI: https://doi.org/10.1016/j.clim.2017.07.001

15. Qiu C. C., Caricchio R., Gallucci S. Triggers of Autoimmunity: The Role of Bacterial Infections in the Extracellular Exposure of Lupus Nuclear Autoantigens. Front Immunol. 2019. Vol. 10. P. 2608. DOI: https://doi.org/10.3389/fimmu.2019.02608.

\section{REFERENCES}

1. Dolgikh VT, Zolotov AN. Immunology. Moscow: Yurayt Publishing House. 2020. p. 248 Available from: https://urait.ru/book/immunologiya-455693

2. Zdor VV, Markelova EV, Geltser BI. [New participants in the violation of tolerance to thyroid antigens: to the concept of immunopathogenesis of autoimmune diseases of the thyroid gland (literature review)]. Medical immunology. 2016;18(3):209-20. Russian.

doi: https://doi.org/10.15789/1563-0625-2016-3-209-220.

3. Matveishina TM, Shtanko IF. [Influence of intrauterine antigenic load on the intensity of distribution of receptors to sialospecific lectins in the structures of the mucous pharynx of rats]. Bulletin of problems of biology and medicine. 2016;129(2):214-9. Ukrainian.

4. Franceschi C, Ostan R, Mariotti S, Monti D, Vitale G. The Aging Thyroid: A Reappraisal Within the Geroscience Integrated Perspective. Endocrine reviews. 2019;40(5):1250-70.

doi: https://doi.org/10.1210/er.2018-00170
5. Tkachenko VI, Maksimets YaA. [Risk factors for the occurrence and progression of autoimmune diseases of the thyroid gland: a systematic analysis of data for the last 10 years]. Family medicine. 2017;5(73):20-25. Ukrainian.

6. Bliddal S, Nielsen $\mathrm{CH}$, Feldt-Rasmussen U. Recent advances in understanding autoimmune thyroid disease: the tallest tree in the forest of polyautoimmunity. F1000Research. 2017;6:1776.

doi: https://doi.org/10.12688/f1000research.11535.1

7. Harrington WE, Kakuru A, Jagannathan P. Malaria in pregnancy shapes the development of foetal and infant immunity. Parasite immunology. 2019;41(3):e12573. doi: https://doi.org/10.1111/pim.12573

8. Hong M, Bertoletti A. Tolerance and immunity to pathogens in early life: insights from HBV infection. Seminars in immunopathology. 2017;39(6):643-52. doi: https://doi.org/10.1007/s00281-017-0641-1

9. Kan B, Razzaghian HR, Lavoie PM. An Immunological Perspective on Neonatal Sepsis. Trends 
in molecular medicine. 2016;22(4):290-302. doi: https://doi.org/10.1016/j.molmed.2016.02.001

10. McLachlan SM, Rapoport B. Breaking tolerance to thyroid antigens: changing concepts in thyroid autoimmunity. Endocrine reviews. 2014;35(1):59-105.

doi: https://doi.org/10.1210/er.2013-1055

11. Marinò $\mathrm{M}$, Latrofa $\mathrm{F}$, Menconi F, Chiovato L, Vitti P. Role of genetic and non-genetic factors in the etiology of Graves' disease. Journal of endocrinological investigation. 2015;38(3):283-94.

https://doi.org/10.1007/s40618-014-0214-2

12. The Aging Thyroid: A Reappraisal Within the Geroscience Integrated Perspective / C. Franceschi et al. Endocr. Rev. 2019. Vol. 40, No. 5. P. 1250-1270. DOI: https://doi.org/10.1210/er.2018-00170
13. Liu $\mathrm{P}$, Zheng J, Yang $\mathrm{P}$, Wang $\mathrm{X}$, Wei $\mathrm{C}$, Zhang S, Feng S, Lan J, He B, Zhao D, Li J, Zhang Y. The immunologic status of newborns born to SARS-CoV2 -infected mothers in Wuhan, China. The Journal of allergy and clinical immunology. 2020;146(1):101109.e1. doi: https://doi.org/10.1016/j.jaci.2020.04.038

14. Köhling HL, Plummer SF, Marchesi JR, Davidge KS, Ludgate M. The microbiota and autoimmunity: Their role in thyroid autoimmune diseases. Clinical immunology (Orlando, Fla.). 2017;183:63-74. doi: https://doi.org/10.1016/j.clim.2017.07.001

15. Qiu CC, Caricchio R, Gallucci S. Triggers of Autoimmunity: The Role of Bacterial Infections in the Extracellular Exposure of Lupus Nuclear Autoantigens.Frontiers in immunology. 2019;10:2608. doi: https://doi.org/10.3389/fimmu.2019.02608

Стаття надійшла до редакції 25.03 .2021 